\title{
CAN SOIL PENETRATION RESISTANCE AND BULK DENSITY BE DETERMINED IN A SINGLE UNDISTURBED SAMPLE?
}

\author{
Carolina Fernandes(1)*, Roniram Pereira da Silva(1) and Adolfo Valente Marcelo(2) \\ (1) Universidade Estadual Paulista, Faculdade de Ciências Agrárias e Veterinária, Campus de Jaboticabal, Jaboticabal, São Paulo, \\ Brasil. \\ (2) Centro Universitário de Rio Preto, São José do Rio Preto, São Paulo, Brasil. \\ * Corresponding author. \\ E-mail: carol@fcav.unesp.br
}

\begin{abstract}
Soil quality indicators such as penetration resistance (PR) and bulk density (BD) are traditionally determined in a single undisturbed soil sample. The aim of this study was to assess the effect of PR measurements of undisturbed samples on the determination of BD in the same sample of two soils differing in clay contents. To this end, samples were collected from the 0.00-0.10 and 0.10-0.20 m layers of two soils of clayey and very clayey texture. Volumetric rings were used to collect a total of 120 undisturbed soil samples from each soil layer that were divided into two subsets containing 60 units each. One sample set, designated "perforated samples", was used to determine PR and BD in the same undisturbed sample; the other, named "intact samples", was used to determine BD only. Bulk density values for perforated and intact samples were compared by analysis of variance, using a completely randomized experimental design. Means were compared by the $t$-test at $5 \%$. The $B D$ values for the clayey soil were similar in perforated and intact samples from the two layers. However, BD of the very clayey soil was lower in the perforated than in the intact samples at both depths. Therefore, $P R$ and $B D$ in clayey soils can be accurately determined in the same undisturbed sample whereas in very clayey soils, different samples are required for this purpose.
\end{abstract}

Keywords: soil physics, Latossolo Vermelho, clayey texture, very clayey texture. 


\title{
RESUMO: É POSSÍVEL DETERMINAR A RESISTÊNCIA DO SOLO À PENETRAÇÃO E A DENSIDADE DO SOLO NA MESMA AMOSTRA INDEFORMADA?
}

\begin{abstract}
A resistência do solo à penetração (RP) e a densidade do solo (Ds), entre outros atributos indicadores da qualidade física do solo, vêm sendo determinadas na mesma amostra indeformada de solo. O objetivo deste trabalho foi avaliar, em dois solos com diferentes teores da fração argila, a influência da determinação da RP sobre os valores da Ds, quando os dois atributos são estimados na mesma amostra indeformada. As amostras indeformadas de solo foram coletadas nas camadas 0,00-0,10 e 0,10-0,20 m, em duas áreas experimentais com classes texturais distintas, textura argilosa e textura muito argilosa. Em cada camada, retiraram-se 120 amostras de solo com anéis volumétricos, totalizando 240 amostras. Desses 120 anéis volumétricos coletados em cada camada, separaram-se dois conjuntos de 60 unidades. Um conjunto foi utilizado para determinar a RP e Ds na mesma amostra indeformada, sendo denominado como "amostras perfuradas". Outro conjunto foi usado para determinar exclusivamente a Ds, sendo denominado como "amostras intactas". Nas comparações dos valores de Ds entre as amostras perfuradas e as intactas, procedeu-se a análise de variância seguindo delineamento inteiramente casualizado. A comparação de médias foi realizada por meio do teste $t$ a $5 \%$. Os valores da Ds com textura argilosa, determinados nas amostras perfuradas, foram semelhantes aos da Ds, definidos nas amostras intactas nas duas camadas avaliadas. Entretanto, no solo com textura muito argilosa, observou-se nas duas camadas avaliadas que os valores da Ds foram menores nas amostras perfuradas do que os determinados nas amostras intactas. Portanto, concluiu-se que a avaliação da RP e Ds na mesma amostra indeformada pode ser realizada em solos com textura argilosa, mas, em solos com textura muito argilosa, a determinação de ambos os atributos deve ser realizada em amostras distintas.
\end{abstract}

Palavras-chave: física do solo, Latossolo Vermelho, textura argilosa, textura muito argilosa.

\section{INTRODUCTION}

Soil penetration resistance (PR) and bulk density (BD) are two soil properties widely used as soil quality indicators for various purposes, for example the assessment of agricultural systems (Imhoff et al., 2000; Araujo et al., 2004; Lima et al., 2010; Mota et al., 2014; Silva and Fernandes, 2014), soil tillage methods (Cavalieri et al., 2006), physical degradation in soils (Giarola et al., 2007), traffic in sugarcane fields (Roque et al., 2011 ), irrigation in soil physical properties (Costa et al., 2014), the least limiting water range for various production systems (Tormena et al., 2007; Blainski et al., 2009; Olibone et al., 2010; Medeiros et al., 2011; Betioli Junior et al., 2012; Araujo et al., 2013) and pedotransfer functions (Fidalski and Tormena, 2007).

In most cases, bulk density is determined after measuring soil penetration resistance in the same undisturbed sample. Particularly when analysing predominantly clayey soils, some particles of the undisturbed sample remain on the metal rod of the penetrometer after measurements. This circumstance is a result of peculiar surface properties of the soil clay fraction. As is well-known, clay particles are highly plastic and sticky, especially when wet (Brady and Weil, 2007), which is typically the case when undisturbed soil samples are subjected to measurements of penetration resistance. As a result, determining bulk density in an undisturbed sample previously used to measure penetration resistance can lead to underestimated values depending on the amount of particles adhered to the penetrometer in the previous operation because bulk density is calculated as the ratio of dry soil mass to total sample volume. Therefore, a reduced amount of soil will lead to an underestimated bulk density value.

Based on the foregoing, the aim of this study was to assess the effect of PR measurements of undisturbed samples on the determination of BD in the same sample of two soils differing in clay contents.

\section{MATERIAL AND METHODS}

This study analysed samples of soil classified as Latossolo Vermelho (Oxisol) based on the criteria of the Brazilian Soil Classification System (Embrapa, 2013). Samples were collected from two experimental areas with different soil textural class. Both were located in the municipality of Jaboticabal, Sao Paulo, Brazil (21 14' 05” S, 48 $17^{\circ}$ '09” W; average height $615 \mathrm{~m}$ a.s.l.) and had been used for sugarcane cultivation with mechanized harvesting for more than 15 years.

The soils were analysed for textural class in disturbed samples from the 0.00-0.10 and 0.10-0.20 m layers. A total of 20 samples per layer and area were collected at randomly selected points. The soils were classified as clayey and very clayey 
based on particle-size analysis as described by Embrapa (1997) (Table 1).

Undisturbed soil samples were collected in October 2011 from the $0.00-0.10$ and $0.10-0.20 \mathrm{~m}$ layers from in-between the sugarcane rows (interrow) after the first harvest. A total of 120 volumetric rings (height $0.05 \mathrm{~m}$, diameter $0.05 \mathrm{~m}$ ) were used, as well as an Uhland sampler to collect the same number of samples from each soil layer. Therefore, a total of 240 samples per experimental area was collected. Sampling points were randomly distributed in an area of ca. 0.5 ha.

The samples from each layer were split into two subsets comprising 60 samples each. One set, designated "perforated samples", was used to determine both bulk density (BD) and soil penetration resistance (PR) in each undisturbed sample; the other, designated "intact samples", was used to determine BD only.

The moisture content of all perforated samples was standardized at $100 \mathrm{hPa}$ on a pressing table, after which the samples were used to measure PR by using a static electronic laboratory penetrometer, as suggested by Tormena et al. (1998). Penetration resistance was measured at the geometric centre of each sample, using a penetration rate

Table 1. Particle-size composition determined by analysis of the soils in two experimental areas with clayey and very clayey soil texture; means of the results at 20 randomly selected points and their standard deviations

\begin{tabular}{lccc}
\hline Soil & Clay & Sand & Silt \\
\hline $\mathrm{m}$ & \multicolumn{3}{c}{$\mathrm{g} \mathrm{kg}^{-1}$} \\
\cline { 2 - 4 } & \multicolumn{3}{c}{ Clayey } \\
$0.00-0.10$ & $441 \pm 20$ & $447 \pm 16$ & $112 \pm 11$ \\
$0.10-0.20$ & $437 \pm 13$ & $457 \pm 09$ & $106 \pm 13$ \\
& & Very clayey \\
$0.00-0.10$ & $680 \pm 06$ & $140 \pm 10$ & $180 \pm 11$ \\
$0.10-0.20$ & $687 \pm 07$ & $132 \pm 09$ & $181 \pm 11$ \\
\hline
\end{tabular}

of $1.0 \mathrm{~cm} \mathrm{~min} \mathrm{~m}^{-1}$ along the sample height $(5 \mathrm{~cm})$. The measurements corresponding to the top and bottom of each sample were discarded, so only those at the three central points were considered in calculations. The sampling frequency of PR recorded at $0.68 \mathrm{~s}$ intervals resulted in a total of 265 values per sample, which were averaged. Any soil particles of an undisturbed sample sticking to the metal rod of the penetrometer were removed with a spatula and returned to the sample. Once PR was measured in all perforated samples, BD was determined according to Grossman and Reinsch (2002). In intact samples, however, only the latter parameter was determined.

The bulk density of perforated and intact samples was subjected to analysis of variance, using a completely randomized design with 60 replications. Means were compared by the $t$-test at $5 \%$. All statistical analysis were performed using software SAS (SAS, 2003).

\section{RESULTS AND DISCUSSION}

The average soil penetration resistance of the 60 perforated undisturbed samples was $2.90 \mathrm{MPa}$ for the $0.00-0.10 \mathrm{~m}$ soil layer and $2.88 \mathrm{MPa}$ for the $0.10-0.20 \mathrm{~m}$ layer in the clayey soil; and 3.38 and $3.26 \mathrm{MPa}$, respectively, in the very clayey soil.

In the clayey soil (contents of $441 \pm 20 \mathrm{~g} \mathrm{~kg}^{-1}$ clay in the $0.00-0.10 \mathrm{~m}$ and $437 \pm 13 \mathrm{~g} \mathrm{~kg}^{-1}$ clay in the 0.10-0.20 m layer), bulk density (BD) was similar in the perforated and intact samples (Table 2). Therefore, $\mathrm{PR}$ and $\mathrm{BD}$ can be determined in a single undisturbed sample of this soil.

However, in the very clayey soil, BD differed between perforated and intact samples in both layers. Thus, the BD values measured in samples previously perforated to measure PR were lower than those determined in intact samples (Table 2), used exclusively to determine BD. The difference resulted from the loss of soil particles sticking to the

Table 2. Analysis of variance for bulk density (BD) values in the 0.00-0.10 and 0.10-0.20 $\mathrm{m}$ layers in soil with clayey and very clayey soil texture

\begin{tabular}{|c|c|c|c|c|}
\hline & \multicolumn{2}{|c|}{ Clayey soil } & \multicolumn{2}{|c|}{ Very clayey soil } \\
\hline & $0.00-0.10 \mathrm{~m}$ & $0.10-0.20 \mathrm{~m}$ & $0.00-0.10 \mathrm{~m}$ & $0.10-0.20 \mathrm{~m}$ \\
\hline Soil sample & $2.01^{\mathrm{ns}}$ & $0.13^{\mathrm{ns}}$ & $6.80^{*}$ & $9.44^{* *}$ \\
\hline \multirow[t]{2}{*}{ CV (\%) } & 1.82 & 2.87 & 1.97 & 2.34 \\
\hline & \multicolumn{4}{|c|}{$\mathrm{BD}\left(\mathrm{kg} \mathrm{dm}^{-3}\right)$} \\
\hline Perforated sample & 1.687 & 1.694 & $1.441 \mathrm{~b}$ & $1.445 \mathrm{~b}$ \\
\hline Intact sample & 1.700 & 1.700 & $1.465 \mathrm{a}$ & $1.478 \mathrm{a}$ \\
\hline LSD & 0.020 & 0.032 & 0.019 & 0.023 \\
\hline
\end{tabular}

ns,* and **: not significant, significant at the 5 and $1 \%$, respectively. LSD: least significant difference. Means followed by different letters in a column were different by the $t$-test at $5 \%$. 
metal rod of the penetrometer and the consequent reduction in dry soil mass measured after ovendrying the perforated samples. Even if most of the particles were removed from the penetrometer and returned to the sample for measurement, a fraction remained that could only be removed with a moist cloth and not be returned to the sample. As a result, BD was underestimated in the very clayey soil (contents of $680 \pm 06 \mathrm{~g} \mathrm{~kg}^{-1}$ clay in the $0.00-0.10 \mathrm{~m}$ layer and $687 \pm 07 \mathrm{~g} \mathrm{~kg}^{-1}$ clay in the 0.10-0.20 m layer), when determined in samples previously used to measure PR. Obviously, due to the high clay content of this soil caused, a greater amount of particles stuck to the penetrometer by effect of the high plasticity and stickiness of the clay fraction (Brady and Weil, 2007).

The time needed to collect undisturbed soil samples in the field justifies the use of a single sample to accurately determine $\mathrm{BD}$ and PR. However, if the clay content of the soil is very high, the use of a single undisturbed soil sample for this purpose can cause an underestimation of $\mathrm{BD}$ values as a result of the loss of clay particles sticking to the penetrometer during PR measurements. Therefore, BD estimates of very clayey soils are inconsistent with field observations and can induce misleading conclusions for different agricultural systems. In such soils, PR and BD should therefore be determined in separate samples.

\section{CONCLUSION}

Accurate measurements of soil penetration resistance and bulk density in a single undisturbed sample are feasible in clayey soil, but not in very clayey soil, for which the two soil properties should be determined in different samples.

\section{REFERENCES}

Araujo FS, Souza ZM, Souza GS, Matsura EE, Barbosa RS. Espacialização do intervalo hídrico ótimo de um Latossolo Vermelho em dois sistemas de colheita de cana-de-açúcar. Pesq Agropec Bras. 2013;48:651-60.

Araujo MA, Tormena CA, Silva AP. Propriedades físicas de um Latossolo Vermelho distrófico cultivado e sob mata nativa. R Bras Ci Solo. 2004;28:337-45.

Betioli Junior E, Moreira WH, Tormena CA, Ferreira CJB, Silva $\mathrm{AP}$, Giarola NFB. Intervalo hídrico ótimo e grau de compactação de um Latossolo Vermelho após 30 anos sob plantio direto. R Bras Ci Solo. 2012;36:971-82.

Blainski E, Gonçalves ACA, Tormena CA, Folegatti MV, Guimarães RML. Intervalo hídrico ótimo num Nitossolo Vermelho distroférrico irrigado. R Bras Ci Solo. 2009;33:273-81.
Brady NC, Weil RR. The nature and properties of soils. 14th.ed. Upper Saddle River: Pearson Higher; 2007.

Cavalieri KMV, Tormena CA, Vidigal Filho PS, Gonçalves ACA, Costa ACS. Efeitos de sistemas de preparo nas propriedades físicas de um Latossolo Vermelho distrófico. R Bras Ci Solo. 2006;30:137-47.

Costa PA, Mota JCA, Romero RE, Freire AG, Ferreira TO. Changes in soil pore network in response to twenty-three years of irrigation in a tropical semiarid pasture from northeast Brazil. Soil Till Res. 2014;137:23-32.

Empresa Brasileira de Pesquisa Agropecuária - Embrapa. Centro Nacional de Pesquisa de Solos. Manual de métodos de análise de solo. $2^{\mathrm{a}}$.ed. Rio de Janeiro: 1997.

Empresa Brasileira de Pesquisa Agropecuária - Embrapa. Sistema brasileiro de classificação de solos. $3^{\text {a }}$.ed. Brasília: Embrapa Solos; 2013.

Fidalski J, Tormena CA. Funções de pedotransferência para as curvas de retenção de água e de resistência do solo à penetração em sistemas de manejo com plantas de cobertura permanente em citros. Ci Rural. 2007;37:1316-22.

Giarola NFB, Tormena CA, Dutra AC. Degradação física de um Latossolo Vermelho utilizado para produção intensiva de forragem. R Bras Ci Solo. 2007;31:863-73.

Grossman RB, Reinsch TG. Bulk density and linear extensibility. In: Dane JH, Topp GC, editors. Methods of soil analysis. Madison: Soil Science Society of America; 2002. Pt 4. p.201-28. (Book series, 5).

Imhoff S, Silva AP, Tormena CA. Aplicações da curva de resistência no controle da qualidade física de um solo sob pastagem. Pesq Agropec Bras. 2000;35:1493-500.

Lima VMP, Magalhães CAS, Oliveira GC, Lima JM. Structural quality of soils cultivated with coffee and pasture in an environmental protection area. R Bras Ci Solo. 2010;34:709-16.

Medeiros JC, Silva AP, Cerri CEP, Giarola NFB, Figueiredo GC, Fracetto FJC. Linking physical quality and $\mathrm{CO}_{2}$ emissions under long-term no-till and conventional-till in a subtropical soil in Brazil. Plant Soil. 2011;338:5-15.

Mota JCA, Alves CVO, Freire AG, Assis Junior RN. Uni and multivariate analyses of soil physical quality indicators of a Cambisol from Apodi Plateau - CE, Brazil. Soil Till Res. 2014;140:66-73.

Olibone D, Olibone APE, Rosolem CA. Least limiting water range and crop yields as affected by crop rotations and tillage. Soil Use Manage. 2010;26:485-93.

Roque AAO, Souza ZM, Araújo FS, Silva GRV. Atributos físicos do solo e intervalo hídrico ótimo de um Latossolo Vermelho distrófico sob controle de tráfego agrícola. Ci Rural. 2011;41:1536-42.

Sas Institute. SAS user's guide: Statistics. Cary, NC: 2003.

Silva RP, Fernandes C. Soil uses during the sugarcane fallow period: Influence on soil chemical and physical properties and on sugarcane productivity. R Bras Ci Solo. 2014;38:575-84.

Tormena CA, Silva AP, Libardi PL. Caracterização do intervalo hídrico ótimo de um Latossolo Roxo sob plantio direto. R Bras Ci Solo. 1998;22:573-81.

Tormena CA, Araújo MA, Fidalski J, Costa JM. Variação temporal do intervalo hídrico ótimo de um Latossolo Vermelho distroférrico sob sistema de plantio direto. R Bras Ci Solo. 2007;31:211-9. 